Article

\title{
Improving Household Agriculture with Roof-Harvested Rainwater: A Case Study in Sydney and Nairobi
}

\author{
Caleb Christian Amos ${ }^{1} \mathbb{D}$, Ataur Rahman ${ }^{1, *}$, Sayka Jahan ${ }^{1}$, John Mwangi Gathenya ${ }^{2}$ (D) \\ and Mohammad A. Alim ${ }^{1}$ (D) \\ 1 School of Engineering, Design and Built Environment Western Sydney University, \\ Penrith, NSW 2751, Australia; calebchristianamos@gmail.com (C.C.A.); S.Jahan@westernsydney.edu.au (S.J.); \\ M.Alim@westernsydney.edu.au (M.A.A.) \\ 2 Soil, Water and Environmental Engineering Department, School of Biosystems and Environmental \\ Engineering, Jomo Kenyatta University of Agriculture \& Technology, Nairobi 00200, Kenya; \\ j.m.gathenya@jkuat.ac.ke \\ * Correspondence: A.Rahman@westernsydney.edu.au
}

Citation: Amos, C.C.; Rahman, A.; Jahan, S.; Gathenya, J.M.; Alim, M.A. Improving Household Agriculture with Roof-Harvested Rainwater: A Case Study in Sydney and Nairobi. Water 2021, 13, 2920. https:// doi.org/10.3390/w13202920

Academic Editor: Fernando António Leal Pacheco

Received: 31 August 2021

Accepted: 14 October 2021

Published: 17 October 2021

Publisher's Note: MDPI stays neutral with regard to jurisdictional claims in published maps and institutional affiliations.

Copyright: (c) 2021 by the authors. Licensee MDPI, Basel, Switzerland. This article is an open access article distributed under the terms and conditions of the Creative Commons Attribution (CC BY) license (https:// creativecommons.org/licenses/by/ $4.0 /)$.

\begin{abstract}
The production and distribution of a sufficient quantity of food and water of satisfactory quality is at the heart of sustainable development. At the small domestic scale, roof-harvested rainwater can make a significant contribution to food supply and distribution systems (production, handling, storage, and transportation). In this paper, we compare the potential crop production of a small garden plot using three methods of watering: (1) rainfed only with no irrigation; (2) irrigated with the ideal amount of water; and (3) rainwater tanks of various sizes installed and used to irrigate the plot. Yield was determined on the basis of the yield calculation method presented in FAO 33. It was found that yields can be increased considerably by installing a correctly managed rainwater storage system (RSS). A $3 \mathrm{~kL}$ RSS connected to a $120 \mathrm{~m}^{2}$ roof can increase yields in Nairobi from $40 \mathrm{~kg}$ to $96 \mathrm{~kg}$. In Sydney, a larger roof of $200 \mathrm{~m}^{2}$ can increase yields from $66 \mathrm{~kg}$ to $143 \mathrm{~kg}$. This study makes an important contribution to water and food security-related sustainable development goals.
\end{abstract}

Keywords: household agriculture; urban agriculture; rainwater harvesting; rainwater storage systems; sustainable housing; nutrition; SDG

\section{Introduction}

Freshwater scarcity is one of the prime challenges that the world is currently facing [1]. The increased stress on water supply systems due to rapid population growth, accelerated urbanization, and climate change-along with improved socio-economic developmenthas increased the demand for both potable and non-potable water [2]. The conflict between limited freshwater resources and increasing water demands have resulted in water shortages in many regions [3]. In addition, changes in rainfall patterns and increased drought days due to climate change have affected numerous countries including Australia, where freshwater scarcity has become a subject of concern [4,5]. Scientists and professionals around the world have been searching for alternative options to satisfy the increasing demand for water in a sustainable way. In this regard, the effective and well-planned harnessing of rainwater can ease the burden on water supply systems and eventually support smarter water use [6].

RWH is not a new idea: it existed even before the advent of large-scale public water supply systems [6,7]. Over recent decades, $\mathrm{RWH}$ has received renewed attention as a potential sustainable water management option [8]. It is one of the most feasible ways to replenish both ground and surface water to meet increasing water demands at smaller scales [6]. RWH systems have been adopted widely in many countries such as Australia, the USA, China, India, Iran, and Brazil, primarily to reduce mains water use [6]. In the agriculture sector, harvested rainwater can also be used to cope with droughts and increase 
crop yields [8-10]. Evidence suggests that roof-harvested rainwater meets the water quality criteria for general agricultural purposes [11].

Household agriculture (HA) can build resilience for food security and nutrition at the household level while contributing to building closer communities by connecting people with the food production system [12,13]. HA also encourages people to make positive dietary changes that lead to better physical and mental health [11,14]. Moreover, HA supports the environment in several ways, such as temperature reduction, infiltration of runoff, and restoration of biodiversity $[15,16]$. Overall, HA entwines notions of food and nutrition security with sustainable environment, as well as ideas of beautification, leisure, exercise, and community interaction [14]. This is particularly beneficial for women, children, and older generations, who typically spend more time at home.

In Australian cities, HA is increasing in popularity and is often referred to as urban agriculture, which also includes urban farms [12] and roadside gardens [13]. This practice is encouraged by many local councils in Australia [17]. It may also play an important role in the economy by initiating small businesses based on HA. This trend seems to be growing throughout the developed world, partly due to increased food prices and a search for higher quality foods, particularly organic foods [18,19].

Developing countries also demonstrate an increasing interest in HA out of necessity or due to cultural reasons. For example, in Cuba, organoponics-raised garden beds in urban centres-receive government support and produce a considerable quantity of food near to the point of consumption [19]. In Lesotho, South Africa, thousands of keyhole gardens have been built over the last decade, which has resulted in notable economic and environmental benefits [20,21]. Water is often a limiting resource in HA and is typically sourced from mains [22]. This puts additional pressure on mains water, particularly during droughts or water restrictions $[23,24]$. Therefore, as recommended by the FAO, the use of an alternative water source, such as harvested rainwater, for HA and urban agriculture may represent a viable option $[23,25,26]$.

In this study, we examined the potential of a RWH system in urban areas of Nairobi (Kenya) and Sydney (Australia), based on several plot sizes and with three different watering methods: (1) rainfed crops without any additional irrigation; (2) irrigated with the ideal quantity of water; and (3) rainwater tanks of various sizes used to irrigate the crops. The intricate relationship between supply and demand was deemed to be a key issue in determining RWH system reliability. The water requirement of crops is primarily a function of evapotranspiration (ETo). RWH systems were modelled using a daily time-step. Daily climate data were acquired for each location, the ETo was calculated based on Food and Agriculture Organisation (FAO) 56 [26], and crop production was estimated using FAO 33 [27]. It is expected that this study will serve as an important reference for policy makers, environmentalists, town planners, and non-governmental organisations (NGOs), and will contribute to achieving the United Nations sustainable development goals (SDGs) related to water and food security.

\section{Materials and Methods}

We selected Parramatta in Sydney (Australia) and Wilson in Nairobi (Kenya) as the study locations. The mean annual rainfall values for Parramatta and Wilson are $960 \mathrm{~mm}$ and $891 \mathrm{~mm}$, respectively (with variation of about 10\% between the two cities). For both Parramatta and Wilson, the wet season lasts for seven months (November to May) and the dry season for five (June to October). The winter season in both Parramatta and Wilson lasts for three months (June to August). The mean maximum and minimum temperatures of Parramatta are $23{ }^{\circ} \mathrm{C}$ and $12{ }^{\circ} \mathrm{C}$, respectively, and $24{ }^{\circ} \mathrm{C}$ and $15{ }^{\circ} \mathrm{C}$ for Wilson. The evapotranspiration values in Parramatta and Wilson are 1351 and $1703 \mathrm{~mm}$, respectively ( $26 \%$ variation between the two cities). These data show that Wilson is drier than Parramatta and, hence, the crop water requirement for Wilson will be higher than that of Parramatta. The common HA/urban agriculture crops for both Parramatta and Wilson are quite similar, e.g., radish, lettuce, parsley, and spinach (grown all year round); broccoli, 
Asian vegetables, and tomatoes (grown all year except in winter); and cauliflower, cabbage, and peas (grown in winter).

In this study, two different roof sizes, $120 \mathrm{~m}^{2}$ and $200 \mathrm{~m}^{2}$, were considered. The former is typical of Kenyan single occupancy houses, while the latter is typical of houses in Parramatta [28]. Garden areas ranged from $1-50 \mathrm{~m}^{2}$ and rainwater storage systems (RSS) of 1-10 $\mathrm{m}^{3}$ were considered to reflect the sizes commonly installed in Australia to meet Building and Sustainability index (BASIX) requirements [29]. The maximum crop yield per $\mathrm{m}^{2}$ was taken as the average value of $7.3 \mathrm{~kg} / \mathrm{m}^{2} /$ year, as reported by Rabin et al. [30] for home food gardens. It should be noted that this study found a huge variety in the yields of home gardens, ranging from 0.44 to $22 \mathrm{~kg} / \mathrm{m}^{2}$, which is in line with the range of 0.22 to $20.17 \mathrm{~kg} / \mathrm{m}^{2}$ as reported by Foeken et al. [31] for Nakuru, Kenya. Both of the selected locations have a piped water supply. It was assumed that all indoor water requirements would be met by the piped water system, while irrigation water would be provided by the RSS.

The daily agro-climatology data used to calculate the daily ETo of the HA area (Table 1) and to perform the RSS water balance included the following:

- Rainfall in $\mathrm{mm} /$ day;

- Maximum and minimum temperature in ${ }^{\circ} \mathrm{C}$;

- Dew point temperature in ${ }^{\circ} \mathrm{C}$, used to calculate relative humidity;

- Solar radiation in $\mathrm{MJ} / \mathrm{m}^{2} /$ day; and

- Wind velocity in $\mathrm{m} / \mathrm{s}$.

Table 1. Summary of selected climate data.

\begin{tabular}{cccc}
\hline Location & Period of Data & Average Annual Rainfall (mm) & ETo \\
\hline Parramatta (Sydney) & $1965-2020$ & 960 & 1351 \\
Wilson (Nairobi) & $1959-1988$ & 891 & 1703 \\
\hline
\end{tabular}

These data were obtained from nearby weather stations according to the method presented in FAO 56. The ETo of Prospect Reservoir, some $15 \mathrm{~km}$ away from the selected site in Sydney, was used. In Kenya, where there was a lack of access to recorded data, satellite was used to supplement the recorded daily rainfall data. Satellite data were obtained from the NASA Langley Research Centre POWER Project [32]. Satellite data are increasingly used for this type of study [33-36]. Maximum and minimum humidity values were calculated from minimum and maximum temperature and the dew point temperature data, following the method presented by Eccel in [37]. Results for ETo were compared with CLIMWAT [38] and the World Meteorological Organization (WMO) [39] averages for validation purposes.

To assess the reliability of the RSS, a daily RSS balance model was used based on the yield after spillage model described by Fewkes and Butler [40]. In the adopted model, the rainfall was regarded as inflow and the release and possible spillage as outflow [41]. It was assumed that RSS is not connected with mains water and, hence, the RSS was not always full. The release from the RSS was estimated by the following equations:

$$
\begin{gathered}
R_{t}=D_{t} \text { if } I_{t}+S_{t-1} \geq D_{t} \\
R_{t}=I_{t}+S_{t-1} \text { if } I_{t}+S_{t-1}<D_{t}
\end{gathered}
$$

where $D_{t}$ is the daily water demand $\left(\mathrm{m}^{3}\right)$ on day $t, S_{t-1}$ is the RSS storage at the end of the previous day $\left(\mathrm{m}^{3}\right), R_{t}$ is release from RSS $\left(\mathrm{m}^{3}\right)$, and $I_{t}$ is inflow $\left(\mathrm{m}^{3}\right)$. Spillage from RSS $\left(S P_{t}\right)\left(\mathrm{m}^{3}\right)$ was calculated by the following equations:

$$
\begin{gathered}
S P_{t}=I_{t}+S_{t-1}-D_{t}-S_{M A X} \text { if } I_{t}+S_{t-1}-D_{t}>S_{M A X} \\
S P_{t}=0 \text { if } I_{t}+S_{t-1}-D_{t} \leq S_{M A X}
\end{gathered}
$$


where $S_{\text {MAX }}$ is the design storage capacity $\left(\mathrm{m}^{3}\right)$ of RSS. The RSS storage $S_{t}$ at the end of day $t$ was computed by:

$$
\begin{gathered}
S_{t}=S_{M A X} \text { if } S P_{t}>0 \\
S_{t}=S_{t-1}+I_{t}-R_{t} \text { if } S P_{t}=0
\end{gathered}
$$

The daily irrigation water demand is a function of the ETo from the HA plot and was also determined on a daily basis using the method outlined in FAO 56 [36] with an assumed crop coefficient value $(\mathrm{Kcb})$ of 1 . The reliability of the RSS is defined by:

$$
\text { Reliability }=\frac{E T a}{E T x}
$$

where ETx is the maximum possible evapotranspiration over the plants' lives with unlimited water supply and ETa is the actual total evapotranspiration over the life of the crop. In practice, ETX is generally greater than Eta as most plants face some level of water restriction in life.

The yield at the end of the growing season $(Y a)$ was calculated using the FAO 33 [37] method, as presented in Equation (8). It is a function of $E T x$ and $E T a$, the yield response factor $(\mathrm{Ky})$, and the maximum crop yield $(Y x)$.

$$
\left(1-\frac{Y a}{Y x}\right)=K y\left(1-\frac{E T a}{E T x}\right)\left(1-\frac{Y a}{Y x}\right)=K y\left(1-\frac{E T a}{E T x}\right)
$$

where $Y a$ is a function of the maximum crop yield, $Y x$ (here taken as $7.3 \mathrm{~kg} / \mathrm{m}^{2} / \mathrm{y}$ ), ETx and $E T a$, and the yield response factor $(K y)$.

\section{Result and Discussion}

The average annual reliability of RSSs, with sizes from 1-10 $\mathrm{m}^{3}$, as compared with rainfed only (None) and unlimited water supply (Mains), is presented in Figure 1.
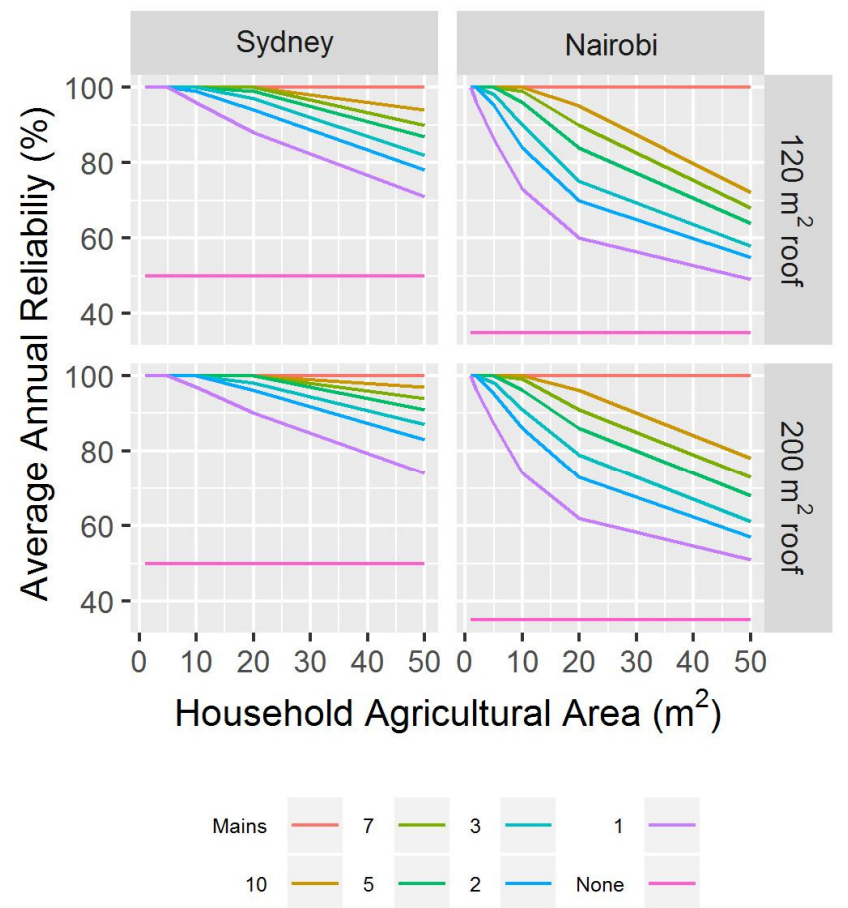

Figure 1. Average annual RSS reliability for various HA areas $\left(1,2, \ldots, 10\right.$ indicate size of RSS in $\left.\mathrm{m}^{3}\right)$.

As can be seen in Figure 1, for the smaller HA (or garden) areas, 100\% reliability can be achieved. As expected, reliability decreases with increasing garden size; however, for 
the larger RSSs, all water needs can be met even for larger areas. In Sydney, the $10 \mathrm{~m}^{3}$ RSS with a $120 \mathrm{~m}^{2}$ roof can provide $94 \%$ reliability for a $50 \mathrm{~m}^{2} \mathrm{HA}$, or, with a $200 \mathrm{~m}^{2}$ roof, reliability increases to $97 \%$. In Nairobi, the corresponding reliabilities are $72 \%$ and $78 \%$, respectively. However, with a $120 \mathrm{~m}^{2}$ roof, Nairobi can still support $20 \mathrm{~m}^{2}$ of $\mathrm{HA} 95 \%$ and $97 \%$ of the time with a $200 \mathrm{~m}^{2}$ roof. Figure 2 presents the corresponding yields.
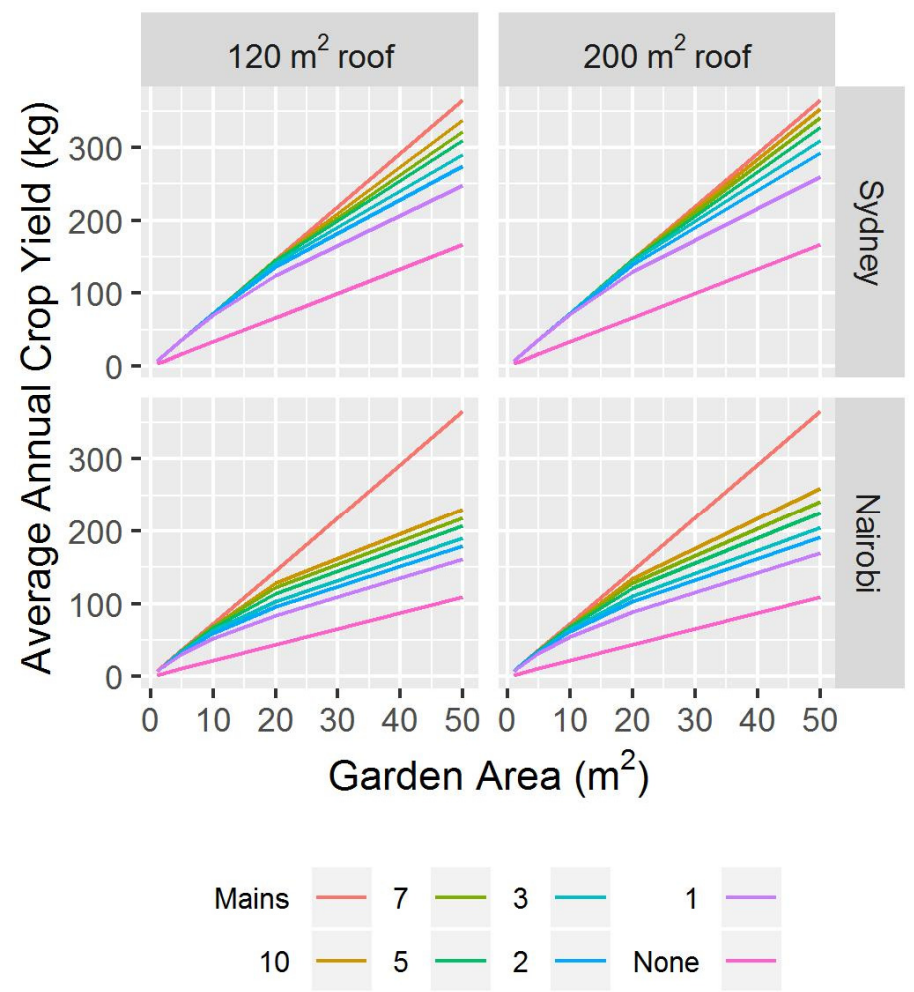

Figure 2. Average annual crop yield $(\mathrm{kg})\left(1,2, \ldots, 10\right.$ indicate size of RSS in $\left.\mathrm{m}^{3}\right)$.

Rainfed reliability was calculated to be $50 \%$ for Sydney and only $35 \%$ in Nairobi, potentially due to the rainfall distribution rather than the annual rainfall, which is similar for both cities. The yields for a $20 \mathrm{~m}^{2} \mathrm{HA}$ area under the rainfed scenario were $67 \mathrm{~kg} / \mathrm{y}$ in Sydney, and $44 \mathrm{~kg} / \mathrm{y}$ in Nairobi, as shown in Figure 2.

For the $120 \mathrm{~m}^{2}$ roof and $20 \mathrm{~m}^{2} \mathrm{HA}$ area, the $10 \mathrm{~m}^{3}$ RSS increased maximum yields to $146 \mathrm{~kg}$ in Sydney and $129 \mathrm{~kg}$ in Nairobi. This represents an increase of $79 \mathrm{~kg}$ and $85 \mathrm{~kg}$ above the rainfed values for Sydney and Nairobi, respectively, demonstrating that Nairobi benefits more than Sydney does from the installation of an RSS system. A $3 \mathrm{~m}^{3}$ RSS connected to the same roof still increased yields from $67 \mathrm{~kg}$ to $142 \mathrm{~kg}$ in Sydney, approaching the maximum yield for this city, and from $44 \mathrm{~kg}$ to $103 \mathrm{~kg}$ in Nairobi. Even a small $1 \mathrm{~kL}$ RSS can considerably improve yields, nearly doubling them from $67 \mathrm{~kg}$ to $125 \mathrm{~kg}$ in Sydney and from $44 \mathrm{~kg}$ to $84 \mathrm{~kg}$ in Nairobi. In fact, for the $20 \mathrm{~m}^{2} \mathrm{HA}$ area, the majority of the increase in yield was realised by a $3 \mathrm{~kL}$ RSS in Sydney and a $5 \mathrm{~kL}$ RSS in Nairobi (Table 2).

Table 2. Average yield (kg/year) for various RSS sizes $\left(\mathrm{m}^{3}\right)$ for $20 \mathrm{~m}^{2}$ household agricultural (HA) area.

\begin{tabular}{ccccccccc}
\hline Location & Roof & Rainfed & $\mathbf{1}$ & $\mathbf{3}$ & $\mathbf{5}$ & $\mathbf{7}$ & $\mathbf{1 0}$ & Full \\
\hline Sydney & 120 & 67 & 125 & 141 & 145 & 146 & 146 & 146 \\
Sydney & 200 & 67 & 129 & 143 & 146 & 146 & 146 & 146 \\
Nairobi & 120 & 44 & 84 & 103 & 114 & 122 & 129 & 146 \\
Nairobi & 200 & 44 & 88 & 111 & 121 & 129 & 135 & 146 \\
\hline
\end{tabular}


The WHO recommendation for healthy nutrition is $400 \mathrm{~g} / \mathrm{p} /$ day of fruit and vegetables, which equates to $146 \mathrm{~kg} / \mathrm{p} /$ year. Even with just the average yield assumed in this study, an HA area of $20 \mathrm{~m}^{2}$ can nearly meet this requirement for one person. It has been suggested that each person requires $18.5 \mathrm{~m}^{2}$ of land to provide their fruit and vegetable needs [42], which is in agreement with the findings presented here.

Yield continues to increase with HA area, simply because all areas are capable of yielding crops even under rainfed conditions. However, in the urban environment, more space is not always available. For various reasons, it may be advantageous to increase the yield of a smaller plot, rather than increasing the area of the plot. It should be noted that Foeken et al. [31] found that, in Nakuru, Kenya, there was an inverse relationship between plot size and yield, with smaller plots yielding more per $\mathrm{m}^{2}$. This, they assume, is because the smaller plots were located closer to living quarters and so were better attended to. This may also mean that they were better watered. They reported a maximum yield of $20.17 \mathrm{~kg} / \mathrm{m}^{2}$, which they related to plots smaller than $10 \mathrm{~m}^{2}$. For plot areas from 10 to $99 \mathrm{~m}^{2}$, an average yield of only $4.73 \mathrm{~m}^{2}$ was recorded. If the average yield, approaching $20 \mathrm{~kg} / \mathrm{m}^{2} /$ year, could be achieved for a $20 \mathrm{~m}^{2} \mathrm{HA}$ area, then the total yield would be $400 \mathrm{~kg}$ /year, or enough for 2.7 people according to the WHO's recommendations. This is a significant contribution to the food supply of a small household.

The average amount of vegetables that can be produced from a $20 \mathrm{~m}^{2}$ plot was determined to be $7.3 \mathrm{~kg} / \mathrm{m}^{2} /$ year, based on a study of 2608 mixed stand communities or home food gardens [30] and assuming three crops per year, as shown in Table 3.

Table 3. Average yield (kg/year) comparisons for various plot sizes.

\begin{tabular}{|c|c|c|}
\hline Location & Plot Size $\left(\mathrm{m}^{2}\right)$ & Max. Crop Yield (kg/m²/Year) \\
\hline Sydney ${ }^{a}$ & 20 & 7.3 \\
\hline Nairobi ${ }^{a}$ & 20 & 7.3 \\
\hline Nakuru b & 20 & 7.21 \\
\hline Nakuru b & 10-99 & 4.73 \\
\hline Nakuru b & 100 & 6.50 \\
\hline East Poket ${ }^{b}$ & 20 & 7.21 \\
\hline East Poket ${ }^{b}$ & $40-60$ & 5.21 \\
\hline East Poket ${ }^{b}$ & 100 & 4.85 \\
\hline New Jersey, USA ${ }^{c}$ & Mixed (mode) & 7.2 \\
\hline New Jersey, USA ${ }^{c}$ & Mixed (upper) & 6.35 \\
\hline
\end{tabular}

$\mathrm{a}=$ This study, ${ }^{\mathrm{b}}=$ Amos et al. [11], ${ }^{\mathrm{c}}=$ Rabin et al. [30].

It should be noted that the analysis in this paper assumes that irrigation takes place at an appropriate time such that there is no water loss through deep percolation, or runoff. Poor irrigation practices wastewater and may reduce the efficiency, reliabilities, and yields reported here. On the other hand, careful management may assist in increasing reliability and efficiency beyond what is reported here. Careful selection of crops with low water requirements and timing of planting, as well as deficit irrigation practices, may also increase reliability and efficiency. Other management techniques such as using shade cloths may reduce evapotranspiration loss. Yield can also be affected by soil quality, pest management, and plant varieties. Plant varieties and diversity also affect the nutritional value of the foods grown. All of these factors point towards a need for the education of home gardeners to achieve widespread successful use of RSS in HA, and to thereby build resilience in food and water supply security. It should be noted that greywater from households can easily be integrated into RSSs and, in such cases, the reliability of the RSS would increase further.

\section{Conclusions}

This study examines the potential crop production of small garden plots using harvested rainwater. It was found that crop yields can be increased considerably in urban household agriculture (HA) by installing an appropriate rainwater storage system (RSS). Yields could potentially be increased further through educated gardening practices. It 
should be noted that increasing agricultural education is an essential component of improving home crop yields, along with increasing the available water supply. There is a need for the widespread education of home gardeners. Moreover, house designs should incorporate $\mathrm{HA}$ as part of the design process, with $20 \mathrm{~m}^{2}$ of HA areas proposed as an appropriate target. This study makes an important contribution to the sustainable development of water and food security for small households.

This study presents a simplistic method of modelling irrigation use; therefore, a more in-depth study focusing on all irrigation uses would be useful. Particular attention should be paid to water requirements, evapotranspiration, and yield. Relationships between total available water, monthly and seasonal variation in rainfall, rainfall categories in the various regions of Australia and Africa, and their influence on reliability and efficiency of RWH systems should also be explored to advance understanding of $\mathrm{RWH}^{\prime}$ s potential in urban agriculture and the contribution it can make to greener cities and attaining sustainable development goals.

Sustainable development, sustainable water management, and food security are integrally related and must be considered together when allocating food and freshwater resources to competing purposes and users. However, in arid and semi-arid regions, water system sustainability and food security often face challenges related to infrastructure, physical resources, and socio-economic conditions. To overcome the challenges present in attaining sustainability in water management and food security, the present study highlights several areas deserving of further research.

The findings of this simulation study should be verified using field observations before being applied in practice. Such a field verification would allow for refinement of the simulation model and the associated findings. It should also be noted that the findings of this study are location specific, and that other locations will have different climatic characteristics and thus will generate different results. Furthermore, the cost of RSSs may need to be subsidised by governments or non-governmental organisations in Africa and other developing countries, as most households in these countries may not be able to afford a large RSS.

Author Contributions: C.C.A. developed the model, carried out the analysis, and drafted the majority of the manuscript; A.R. provided feedback on the analysis, wrote part of the manuscript, and supervised the study; S.J. carried out the literature review, wrote part of the manuscript, and edited the manuscript; J.M.G. assisted in the data analysis, provided feedback, and supervised the study; and M.A.A. provided feedback on the study and edited the manuscript. All authors have read and agreed to the published version of the manuscript.

Funding: The research received no external funding.

Institutional Review Board Statement: No human or animal was involved with this study and hence ethics approval was not needed.

Informed Consent Statement: This section is not relevant to our study.

Data Availability Statement: The rainfall and climatic data used in this study can be obtained from Government of Australia and Kenya by paying a prescribed fee.

Acknowledgments: The authors would like to acknowledge both the Australian and Kenyan Bureaus of Meteorology and the NASA Langley Research Center POWER Project funded through the NASA Earth Science Directorate Applied Science for the rainfall and climate data.

Conflicts of Interest: The authors declare no conflict of interest.

\section{References}

1. Yousefi, M.; Ghalehaskar, S.; Asghari, F.B.; Ghaderpoury, A.; Dehghani, M.H.; Ghaderpoori, M.; Mohammadi, A.A. Distribution of fluoride contamination in drinking water resources and health risk assessment using geographic information system, northwest Iran. Regul. Toxicol. Pharmacol. 2019, 107, 104408. [CrossRef] [PubMed]

2. Alim, M.A.; Rahman, A.; Tao, Z.; Samali, B.; Khan, M.M.; Shirin, S. Suitability of roof harvested rainwater for potential potable water production: A scoping review. J. Clean. Prod. 2020, 248, 119226. [CrossRef] 
3. Stoeglehner, G.; Edwards, P.; Daniels, P.; Narodoslawsky, M. The water supply footprint (WSF): A strategic planning tool for sustainable regional and local water supplies. J. Clean. Prod. 2011, 19, 1677-1686. [CrossRef]

4. Awange, J.; Hu, K.; Khaki, M. The newly merged satellite remotely sensed, gauge and reanalysis-based Multi-Source WeightedEnsemble Precipitation: Evaluation over Australia and Africa (1981-2016). Sci. Total Environ. 2019, 670, 448-465. [CrossRef] [PubMed]

5. Alim, M.A.; Rahman, A.; Tao, Z.; Samali, B.; Khan, M.M.; Shirin, S. Feasibility analysis of a small-scale rainwater harvesting system for drinking water production at Werrington, New South Wales, Australia. J. Clean. Prod. 2020, 270, 122437. [CrossRef]

6. Aladenola, O.O.; Adeboye, O.B. Assessing the Potential for Rainwater Harvesting. Water Resour. Manag. 2010, 24, $2129-2137$. [CrossRef]

7. AbdelKhaleq, R.A.; Ahmed, I.A. Rainwater harvesting in ancient civilizations in Jordan. Water Sci. Technol. Water Supply 2007, 7 , 85-93. [CrossRef]

8. Gómez, Y.D.; Teixeira, L.G. Residential rainwater harvesting: Effects of incentive policies and water consumption over economic feasibility. Resour. Conserv. Recycl. 2017, 127, 56-67. [CrossRef]

9. Lani, N.H.M.; Yusop, Z.; Syafiuddin, A. A Review of Rainwater Harvesting in Malaysia: Prospects and Challenges. Water 2018, 10, 506. [CrossRef]

10. Jones, M.P.; Hunt, W.F. Performance of rainwater harvesting systems in the southeastern United States. Resour. Conserv. Recycl. 2010, 54, 623-629. [CrossRef]

11. Amos, C.; Rahman, A.; Gathenya, J.; Friedler, E.; Karim, F.; Renzaho, A. Roof-Harvested Rainwater Use in Household Agriculture: Contributions to the Sustainable Development Goals. Water 2020, 12, 332. [CrossRef]

12. Russ Grayson, A.R.R.; Bradley, K. Urban Farming. In Organic Gardener; ABC Books: St Leonards, Australia, 2017.

13. Marshall, T. On the Verge. In Organic Gardener; ABC Books: St Leonards, Australia, 2017.

14. Pollard, G.; Ward, J.; Roetman, P. Water Use Efficiency in Urban Food Gardens: Insights from a Systematic Review and Case Study. Horticulturae 2018, 4, 27. [CrossRef]

15. Goddard, M.; Dougill, A.; Benton, T. Scaling up from gardens: Biodiversity conservation in urban environments. Trends Ecol. Evol. 2010, 25, 90-98. [CrossRef]

16. Lupia, F.; Pulighe, G. Water use and urban agriculture: Estimation and water saving scenarios for residential kitchen gardens. Agric. Agric. Sci. Procedia 2015, 4, 50-58. [CrossRef]

17. Sydney, C.O. Footpath Gardening Policy. Australia. 2017. Available online: www.cityofsydney.nsw.gov (accessed on 9 March 2019).

18. Mok, H.-F.; Williamson, V.G.; Grove, J.R.; Burry, K.; Barker, F.; Hamilton, A.J. Strawberry fields forever? Urban agriculture in developed countries: A review. Agron. Sustain. Dev. 2013, 34, 21-43. [CrossRef]

19. Hamilton, A.J.; Burry, K.; Mok, H.-F.; Barker, F.; Grove, J.R.; Williamson, V.G. Give peas a chance? Urban agriculture in developing countries. A review. Agron. Sustain. Dev. 2014, 34, 45-73. [CrossRef]

20. Billingsley, R.; Mothunyane, M.; Thabane, M.; McLean, S. Lessons from Lesotho: How 'Joined-Up'Approach, Centred on Key-Hole Gardens, Is Tackling Linked Issues of Hunger, Nutrition and Poverty, Hunger, Nutrition, Climate Justice, a New Dialogue: Putting People at the Heart of Global Developmen. Dublin. 2013. Available online: https://www.mrfcj.org/wpcontent/uploads/2015/09/2013-04-16-Lesotho.pdf (accessed on 9 March 2019).

21. Eigenbrod, C.; Gruda, N. Urban vegetable for food security in cities. A review. Agron. Sustain. Dev. 2015, 35, 483-498. [CrossRef]

22. Parece, T.E.; Lumpkin, M.; Campbell, J.B. Irrigating Urban Agriculture with Harvested Rainwater: Case Study in Roanoke, Virginia, USA. In The Hand Book of Environmental Chemistry; Younos, T., Parece, T.E., Eds.; Springer: Cham, Switzerland, 2016; Volume 3, pp. 154-196.

23. Abbasi, T.; Abbasi, S.A. Sources of pollution in rooftop rainwater harvesting systems and their control: Critical review. Environ. Sci. Technol. 2011, 41, 2097-2167. [CrossRef]

24. Hejazi, M.I.; Edmonds, J.; Clarke, L.; Kyle, P.; Davies, E.; Chaturvedi, V.; Wise, M.; Patel, P.; Eom, J.; Calvin, K. Integrated assessment of global water scarcity over the 21st century under multiple climate change mitigation policies. Hydrol. Earth Syst. Sci. 2014, 18, 2859-2883. [CrossRef]

25. Despins, C.; Farahbakhsh, K.; Leidl, C. Assessment of rainwater quality from rainwater harvesting systems in Ontario, Canada. J. Water Supply Res. Technol.-AQUA 2009, 58, 117-134. [CrossRef]

26. Allen, R.G.; Pereira, L.S.; Raes, D.; Smith, M. Crop Evapotranspiration-Guidelines for Computing Crop Water Requirements-FAO Irrigation and Drainage Paper 56; FAO: Rome, Italy, 1998; p. D05109.

27. Doorenbos, J.; Kassam, A. FAO 33: Yield response to water. Irri. Drain. Pap. 1979, 33, 257.

28. Amos, C.C.; Rahman, A.; Gathenya, J.M. Economic Analysis of Rainwater Harvesting Systems Comparing Developing and Developed Countries: A Case Study of Australia and Keny. J. Clean. Prod. 2018, 172 (Suppl. C), 196-207. [CrossRef]

29. BASIX. Data Reporting Period: July 2005-June 2015. 2016. Available online: http://datareporting.planning.nsw.gov.au/ reporting/basix/pdf.action (accessed on 12 March 2019).

30. Rabin, J.; Zinati, G.; Nitzsche, P. Yield expectations for mixed stand, Small-Scale Agriculture. Sustain. Farm. Urban Fringe 2012, 7, $1-4$.

31. Foeken, D.W.J.; Owuor, S.; Klaver, W. Crop Cultivation in Nakuru Town, Kenya: Practice and Potential; ASC Working Papers; African Studies Centre: Nairobi, Kenya, 2002. 
32. NASA. NASA Power Data Access Viewer 2019. 2019. Available online: https://power.larc.nasa.gov/data-access-viewer/ (accessed on 12 March 2019).

33. Munzimi, Y.A.; Hansen, M.C.; Adusei, B.; Senay, G.B. Characterizing Congo Basin Rainfall and Climate Using Tropical Rainfall Measuring Mission (TRMM) Satellite Data and Limited Rain Gauge Ground Observations. J. Appl. Meteorol. Clim. 2015, 54, 541-555. [CrossRef]

34. Prakash, S.; Mitra, A.K.; Momin, I.M.; Pai, D.S.; Rajagopal, E.N.; Basu, S. Comparison of TMPA-3B42 versions 6 and 7 precipitation products with gauge-based data over India for the southwest monsoon period. J. Hydrometeorol. 2015, 16, 346-362. [CrossRef]

35. Ciabatta, L.; Brocca, L.; Moramarco, T.; Wagner, W. Comparison of different satellite rainfall products over the Italian territory. In Engineering Geology for Society and Territory; Springer: Cham, Switzerland, 2015; Volume 3, pp. 623-626.

36. Li, D.; Ding, X.; Wu, J. Simulating the regional water balance through hydrological model based on TRMM satellite rainfall data. Hydrol. Earth Syst. Sci. 2015, 12, 2497-2525.

37. Eccel, E. Estimating air humidity from temperature and precipitation measures for modelling applications. Meteorol. Appl. 2012, 19, 118-128. [CrossRef]

38. FAO. CLIMWAT 2019. 19 November 2019. Available online: http://www.fao.org/land-water/databases-and-software/climwatfor-cropwat/en/ (accessed on 12 March 2019).

39. WMO. World Weather Information Service: Nakuru. Kenya 2019. 4 December 2019. Available online: http:/ / worldweather.wmo. int/en/city.html?cityId=518 (accessed on 12 March 2019).

40. Fewkes, A.; Butler, D. Simulating the performance of rainwater collection and reuse systems using behavioural models Building Services. Int. J. Eng. Res. Technol. 2000, 21, 99-106.

41. Hajani, E.; Rahman, A. Reliability and cost analysis of a rainwater harvesting system in periurban regions of Greater Sydney, Australia. Water 2014, 6, 945-960. [CrossRef]

42. Iannotti, M. How Much to Plant Per Person in the Vegetable Garden. 29 September 2019. Available online: https://www. thespruce.com/how-many-vegetables-per-person-in-garden-1403355 (accessed on 12 March 2019). 